\title{
In vivo nematicidal potential of camel milk on Heligmosomoides polygyrus gastro-intestinal nematode of rodents
}

\author{
D. ALIMI ${ }^{12 *}$, A. ABIDI ${ }^{1}$, E. SEBAI ${ }^{1}$, M. REKIK ${ }^{3}$, R. M. MAIZELS ${ }^{4}$ M. DHIBI ${ }^{1}$, H. AKKARI ${ }^{1}$
}

${ }^{1}$ Laboratoire de Parasitologie, Université de la Manouba, École Nationale de Médecine Vétérinaire de Sidi thabet, 2020, Tunisia, *E-mail: dhouha.enmv@gmail.com; '²Faculté des sciences de Bizerte, Université de Carthage, 7021, Zarzouna, Tunisia; ${ }^{3}$ International Center for Agricultural Research in the Dry Areas (ICARDA), P.O. Box, 950764 Amman 11195, Jordan; ${ }^{4}$ Wellcome Trust Centre for Molecular Parasitology, Institute of Infection, Immunology and Inflammation, University of Glasgow, Sir Graeme Davies Building, 120 University Place, Glasgow G12 8TA, UK

Article info

Received August 11, 2017 Accepted January 2, 2018

\begin{abstract}
Summary
Following our previous findings on the in vitro anthelmintic effect of camel milk on Haemonchus contortus, the current study aimed at investigating its in vivo effect. Investigations were carried out using mice infected with Heligmosomoides polygyrus which is a parasite commonly used to test the efficacy of anthelmintics. Thirty six Swiss white mice of both sexes aged $5-6$ weeks old, and weighing between 20 and $25 \mathrm{~g}$ were orally infected with $0.5 \mathrm{ml}$ dose of 100,1 -week-old $\mathrm{H}$. polygyrus infective larvae $\left(\mathrm{L}_{3}\right)$. After the pre-patent period, infected animals were randomly divided into 6 groups of 6 animals each. The nematicidal efficacy of camel milk was monitored through faecal egg count reduction (FECR) and total worm count reduction (TWCR). Four doses (8.25; 16.5; 33.0; $66.0 \mathrm{ml} / \mathrm{kg}$ body weight (bw)) for fresh camel milk and $22 \mathrm{mg} / \mathrm{kg}$ bw for albendazole were studied using a bioassay. Albendazole and $4 \%$ dimethylsulfoxide were included in the protocol as reference drug and placebo, respectively. For all tested doses except $8.25 \mathrm{ml} / \mathrm{kg}$ bw, camel milk was effective in vivo against $H$. polygyrus reducing both faecal egg count and worm count $(p<0.05)$. The dose $66 \mathrm{ml} / \mathrm{kg}$ bw showed the highest nematicidal activity causing a $76.75 \%$ FECR and a $69.62 \%$ TWCR 7 day after initiating the treatment. These results support the possible use of camel milk in the control of gastro-intestinal helminthiasis.
\end{abstract}

Keywords: Camel milk; Faecal egg count reduction; Heligmosomoides polygyrus; Total worm count reduction

\section{Introduction}

The impact of gastrointestinal nematode (GIN) infection in small ruminants is linked to clinical signs associated with infection and also to subclinical economic losses (Martinez-Valladares et al., 2015). Compared to other nematodes, Haemonchus contortus is one of the most abundant and prevalent gastrointestinal parasites in sheep and goats in Tunisia (Akkari et al., 2013; Rouatbi et al., 2016). The parasite can cause acute disease and high mortality in all categories of livestock. To date, the current mode of control of gastrointestinal parasitism relies on the repeated use of synthetic anthelmintics in combination with grazing management. However, the frequent use of these anthelmintics over many years leads to the emergence of drug resistant strains of parasites (Miller et al., 2012). Even with optimally timed strategic treatments, this type of control is expensive, requires efficient health delivery systems particularly in remote production areas and, in most cases, is only partially effective (Ademola et al., 2004). Therefore, there is an obvious need for, and significant global interest in the development of alternative improved means of controlling parasitic nematodes

\footnotetext{
$\bar{*}$ - corresponding author
} 
(Britton et al., 2015). In this respect, identifying therapeutically effective agents from natural products may reduce the risk of toxicity when the drug is used clinically and provide livestock farmers with environmentally friendly, easily accessible and not costly options (Lahlou, 2013).

Milk has shown positive results in controlling gastro-intestinal nematodes. Early reports suggested that milk exerted an anthelmintic effect on existing strongyle infections in foals (Leese, 1943) and on nematode infections in pigs (Spindler \& Zimmerman, 1944; Spindler et al., 1944; Shorb \& Spindler, 1947). Calves fed entirely on milk had fewer, smaller $H$. contortus infection than calves fed "a normal diet" composed of cow's milk, alfalfa hay and grain (Porter, 1941). In addition, lower numbers of $H$. placei, Cooperia spp. and Oesophagostomum radiatum were found in suckled calves than in weaned counterparts (Rohrbacher et al., 1958). Milk proteins, or components associated with these proteins, reduced the motility of both sheathed and exsheathed $\mathrm{L}_{3}$ Teladorsagia circumcincta in in vitro and in vivo studies performed by Zeng et al. (2001; 2003). Camel milk is highly nutritious (Abbas et al., 2013), and also has valuable medicinal and protective properties mainly due to its high concentration of immunoglobulins. Nutritional benefits of camel milk have been reported by several studies which included antihypertensive, hypoglycaemic (Agrawal et al., 2003; 2011) and hypocholesterolaemic effects (Agrawal et al., 2005). Moreover, camel milk is considered as an alternative to bovine milk for children who are allergic to bovine milk (Abusheliabi et al., 2016; Al Haj \& Al Kanhal, 2010; El-Agamy et al., 2009). Scientific evidence is also building up that camel milk is unique for its therapeutic properties in terms of antioxidative factors (Kula, 2015), antibacterial (Benkarroum et al., 2004), antiviral and antifungal activities (Yassin et al., 2015; Abdel Galil \& Alhaider, 2016).

In a preliminary study, our group demonstrated for the first time the in vitro nematicidal effect of camel milk against $H$. contortus, a gastrointestinal nematode of ruminants (Alimi et al., 2016) and we were not aware of any published work investigating the in vivo anthelmintic effects of camel milk.

Therefore, the current study aimed to assess the in vivo nematicidal potential of camel milk against the rodent nematode, Heligmosomoides polygyrus. $H$. polygyrus belongs to the superfamily Trichostrongiloidea as do most nematodes of veterinary importance (Githiori et al., 2003a; 2003b) and its biological cycle is easily maintained in the laboratory mouse (Mus musculus). H. polygyrus is a standard experimental model used for routine screening of potential drug candidates (Githiori et al., 2003a).

\section{Materials and Methods}

\section{Experimental Animals}

Mice

Albino Swiss mice $(n=36)$, of both sexes age 5 to 6 weeks and weighing between 20 to $25 \mathrm{~g}$, were used. Animals were obtained from the animal house of the Higher Institute of Biotechnology of Beja (University of Jendouba, Tunisia). Mice were housed in polypropylene cages with steel wire tops in an air conditioned room ( $22 \pm 1{ }^{\circ} \mathrm{C}, 45-75 \%$ relative humidity) maintained in a controlled atmosphere of $12 \mathrm{~h}$ light/12 $\mathrm{h}$ dark cycle. Food and water were provided ad libitum.

\section{Helminth parasite}

Infective third stage larvae $\left(\mathrm{L}_{3}\right)$ of $H$. polygyrus were generously provided by Dr. Rick Maizels, University of Edinburgh, UK. The parasite was cultured from the egg to $L_{3}$ stage in Petri dishes containing wet filter paper. Briefly, egg-containing faecal materials were macerated in the wet filter paper and incubated till they hatch into the first larval $\left(L_{1}\right)$ stage, which underwent several stages of moulting before emerging as the third stage infective larvae (Adiel et al., 2013).

Table 1. Faecal egg count (FEC) and \% reduction of FEC at days 3, 5 and 7 after treatment with $4 \%$ dimethylsulfoxide (DMSO), albendazole and different doses of camel milk.

\begin{tabular}{lccccc}
\hline Group & Dose & $\mathbf{D}_{0}$ & $\mathbf{D}_{3}$ & $\mathbf{D}_{5}$ & $\mathbf{D}_{\mathbf{7}}$ \\
\hline DMSO (4\%) & - & $11000 \pm 9899$ & $19000 \pm 4242$ & $16590 \pm 1254$ & $23870 \pm 2440$ \\
& & & $(0.0)$ & $(0.0)$ & $(0.0)$ \\
\hline $\begin{array}{l}\text { Albendazole } \\
\text { (mg/Kg bw) }\end{array}$ & 22 & $26500 \pm 2687$ & $6161 \pm 1328^{\mathrm{c}}$ & $13275 \pm 4631$ & $2940 \pm 226^{\mathrm{c}}$ \\
& & & $(\mathbf{6 7 . 5 7 )}$ & $(\mathbf{1 9 . 9 8 )}$ & $(\mathbf{8 7 . 6 8 )}$ \\
\hline & 8.25 & $6403 \pm 855$ & $15111 \pm 5727^{\mathrm{a}}$ & $13360 \pm 1966$ & $19420 \pm 3012^{\mathrm{a}, \mathrm{b}}$ \\
& & & $(18.42)$ & $(\mathbf{1 9 . 8 3 )}$ & $(\mathbf{1 8 . 7 3 )}$ \\
Camel milk & 16.5 & $8705 \pm 714$ & $11187 \pm 2022$ & $12325 \pm 318$ & $15440 \pm 636^{\mathrm{a}, \mathrm{b}}$ \\
(mL/Kg bw) & & & $(\mathbf{4 2 . 1 1 )}$ & $(\mathbf{2 5 . 3 2 )}$ & $(34.23)$ \\
& 33 & $14300 \pm 990$ & $13203 \pm 424$ & $11905 \pm 1124$ & $10180 \pm 318^{\mathrm{a}, \mathrm{b}}$ \\
& & & $(\mathbf{3 0 . 7 9 )}$ & $(\mathbf{2 8 . 2 4 )}$ & $(\mathbf{5 6 . 5 7 )}$ \\
& 66 & $16910 \pm 523$ & $8022 \pm 566^{\mathrm{b}}$ & $5350 \pm 424^{\mathrm{b}}$ & $5550 \pm 537^{\mathrm{a}, \mathrm{b}}$ \\
\end{tabular}

${ }^{a} p<0.05$ comparison with positive control group (Albendazole)

${ }^{\mathrm{b}} \mathrm{p}<0.05$ comparison with negative control group (DMSO $4 \%$ )

${ }^{c} p<0.05$ positive control group vs. negative control group 


\section{Test compounds}

Preparation of the Albendazole solution

For the reference drug, albendazole $(99.8 \%$ pure standard reference, Médivét, S.A., Tunisia), 50 milligrams were diluted with $0.8 \mathrm{ml}$ of DMSO and then distilled water was added to obtain the final volume of $50 \mathrm{ml}$. The obtained solution had a concentration of $1 \mathrm{mg} / \mathrm{ml}$. A unique dose of $22 \mathrm{mg} / \mathrm{kg}$ bw of albendazole was administered. The $4 \%$ DMSO was used in the in vivo assay as placebo (negative control) (Yondo et al., 2013).

\section{Camel milk}

For 6 consecutive days in November 2016, camel milk samples were collected early morning from a camel farm located in the district of Sidi Bouzid (central Tunisia). Milk was recovered by hand milking. Samples were collected in sterile screw bottles and kept in cooling boxes $\left(4^{\circ} \mathrm{C}\right)$ until transported to the laboratory for immediate use.

\section{Experimental design}

Animals were screened for helminth parasites and subsequently treated with $7.5 \mathrm{mg} / \mathrm{kg}$ bw of albendazole to eliminate any roundworm infection. Then, the mice were randomly allocated into cages and allowed to acclimatize for 1 week. They had access to food and water ad libitum. In all studies, a dose of $\approx 100$, 1-weekold $H$. polygurus infective larvae $\left(\mathrm{L}_{3}\right)$ was used to infect the mice, contained in $0.5 \mathrm{ml}$ of distilled water. The mice were infected orally using an oral gavage needle $(0.6 \times 0.9 \mathrm{~mm})$.

After the pre-patent period (9 to 11 days) (Smyth, 1996), infected mice were randomly allocated into 6 groups of 6 individuals each and treated as follows:

Group 1: 4 \% DMSO (negative control);

Group 2: 22 mg of Albendazole $\mathrm{kg}^{-1}$ bw (positive control);

Group 3: $8.25 \mathrm{ml}$ of camel milk kg-1 bw;

Group 4: $16.5 \mathrm{ml}$ of camel milk kg-1 bw;

Group 5: $33 \mathrm{ml}$ of camel milk kg-1 bw;

Group 6: $66 \mathrm{ml}$ of camel milk kg-1 bw;

Groups 3 to 6 were treated orally with fresh camel milk at the different studied doses for 6 consecutive days (Day 9 to Day 14), while group 2 was treated with a single dose of albendazole $(22 \mathrm{mg} /$ $\mathrm{kg} \mathrm{bw}$ ) as standard anthelmintic (positive control) on Day 9.

\section{Mice faecal samples}

From Day 9 to Day 16 mice were isolated in individual cages to collect faecal pellets. For each mouse, a sample of faecal material was collected early in the morning before administration of the treatment on Days 9, 12, 14 and also on Day 16. Faecal pellets were immediately collected with a teaspoon, and placed in labelled Petri dishes containing $0.5-1 \mathrm{ml}$ distilled water to prevent faecal materials from drying out. Faecal egg count was calculated as eggs per gram (EPG) of the faecal material according to the McMaster technique (Thienpont et al., 1979). In brief, $2 \mathrm{~g}$ of this specimen was weighed, homogenized in a porcelain mortar and sus- pended in $60 \mathrm{ml}$ saturated salt solution $(0.4 \% \mathrm{NaCl})$ (Thienpont et al., 1979). Aliquots were mixed thoroughly with a Pasteur pipette and an equal volume of the suspension was introduced quickly under each of the two McMaster chambers (Hawksley, England) and viewed under a light microscope (10 $\mathrm{x}$ magnification).

The EPG was calculated according to the equation: (number of eggs counted $\mathrm{x}$ total volume)/ (volume counted $\mathrm{x}$ weight of faecal material).

The faecal egg count reduction (FECR) was determined by the following formula (Coles et al., 1992): FECR ( \%) = 100 (1- T/C); $\mathrm{T}$ : means of FEC in the treated groups; $\mathrm{C}$ : means of FEC in the control groups.

\section{Worm recovery}

On Day 16 (8 days after the start of the treatments), mice were humanely euthanized using chloroform, and the body cavity was opened to remove the small intestine. This organ was placed in labelled Petri dishes containing $20-30 \mathrm{ml}$ of distilled water and opened longitudinally with small scissors. The intestine was passed through the arm of a small forceps and the exudate containing parasites was washed in water (Githiori, 2004). The percentage of total worm count reduction (TWCR) was calculated by the method described by Enriquez (1993): TWCR ( \%) = $100 \times$ (Total worm count in control group - Total worm count in treated group)/ Total worm count in control group.

\section{Statistical analysis}

The statistical analysis was done using STATVIEW v.5.0.1 software (SAS Institute, Cary, NC). The comparisons of means for FEC and TWC were done using analysis of variance (ANOVA) followed by Fisher's PLSD and all data were reported as mean \pm standard deviation. Differences were considered to be statistically significant when the $p$-value was less than 0.05 .

\section{Ethical Approval and/or Informed Consent}

Mice were housed and maintained in a pathogen-free environment at the Department of Comparative Medicine. All experiments were performed according to the protocol No (NIH publication 86-23 revised 1985) USA, approved by (National Ethic Committee of Tunis University) IACUC.

\section{Results}

\section{Faecal egg count reduction (FECR)}

At $D_{0}$ of the administration of the treatment (corresponding to Day 9 of the experiment), mean FEC varied from $6403 \pm 855$ to $26500 \pm 2687$ (Table 1). For the lowest two doses of camel milk ( 8.25 and $16.5 \mathrm{ml} / \mathrm{kg} \mathrm{bw}$ ) and for the negative control (4\% DMSO) group, the mean FEC increased throughout the treatment period. This increase was highly significant $(p<0.05)$ when compared with groups that received fresh camel milk and albendazole. Treat- 
Table 2. Mean worm intensity and \% reduction of TWC at day 7 after treatment with $4 \%$ dimethylsulfoxide, albendazole and different doses of camel milk.

\begin{tabular}{lccc}
\hline Group & $\begin{array}{c}\text { Dose } \\
(\mathrm{mg} / \mathrm{kg})\end{array}$ & $\begin{array}{c}\text { Mean worm intensity } \\
\text { after treatment } \pm \\
\text { standard deviation }\end{array}$ & $\begin{array}{c}\text { \% reduction } \\
\text { of total worm } \\
\text { count (TWCR) }\end{array}$ \\
\hline DMSO & - & $79.33 \pm 12.5^{\mathrm{a}}$ & 0 \\
\hline $\begin{array}{l}\text { Albendazole } \\
\text { (mg/kg bw) }\end{array}$ & 22 & $19.25 \pm 4^{\mathrm{b}}$ & 75.95 \\
\hline & 8.25 & $70.5 \pm 7.8^{\mathrm{a}, \mathrm{c}}$ & 11.39 \\
Camel Milk & 16.5 & $61.8 \pm 10.7^{\mathrm{c}}$ & 22.78 \\
(mL/kg bw) & 33 & $37.8 \pm 4.26^{\mathrm{d}}$ & 53.16 \\
& 66 & $24.33 \pm 4.1^{\mathrm{b}}$ & 69.62 \\
\hline
\end{tabular}

$a, b, c, d$, numbers with the same letter in the same column are not significantly different at $p<0.05$.

TWC: total worm count; TWCR: total worm count reduction; DMSO: dimethylsulfoxide

ment with albendazole was associated with a significant reduction in FEC $(p<0.05)$ starting day 3 post treatments, but this reduction was not significant on day 5 . In this assay, albendazole was more active in comparison to the tested camel milk, but this commercial anthelmintic failed to show complete effectiveness (87.68 \%) in infected mice. The dose rate $66 \mathrm{ml} / \mathrm{kg}$ bw for camel milk showed a nematicidal activity of (76.75\%). FECR was dose dependent.

Effects of camel milk and albendazole on the parasitic intensity of the nematode/Total worm count reduction (TWCR)

Albendazole was the most effective, causing a reduction of $75.95 \%$ in TWC, while camel milk produced $69.62 \%$ reduction at $66 \mathrm{ml} / \mathrm{kg}$ bw (Table 2). Results from albendazole and the highest dose of camel milk were not different $(p>0.05)$. Reduction of the TWC by camel milk was dose dependent (Table 2); the lowest dose rate $(8.25 \mathrm{ml} / \mathrm{kg} \mathrm{bw})$ was associated with a TWC not different from the negative control (4\% DMSO), i.e. $0 \%$ of TWCR (Table 2).

\section{Discussion}

In a preliminary study, in vitro tests have been undertaken and camel milk showed a nematicidal effect against $H$. contortus, a gastro-intestinal nematode of sheep, reducing egg hatching and adult worm motility by $100 \%$ at a concentration close to $100 \mathrm{mg} /$ $\mathrm{ml}$ (Alimi et al., 2016). The current study was performed to validate the anthelmintic activity of camel milk in vivo using $H$. polygyrus. Our study revealed that, fresh camel milk significantly reduced the FEC and the TWC of $H$. polygyrus. This activity was more visible at the dose $66 \mathrm{ml} / \mathrm{kg}$ bw by day 7 post-treatment, and resulted in a $76.75 \%$ reduction of FECR and $69.62 \%$ reduction of TWCR. This activity was dose and time dependent. We thought that, camel milk affect both the reproduction system of the worm and the infra-population. Also, our findings clearly demonstrated a reduction of parasite burdens in mice receiving camel milk; the reduction being evident 3 days after the start of the treatment. In fact, this reduction in egg count is an indication of reduced fecundity.

The possible explanation for such a decrease may be attributed to high amounts of proteins and peptides such as lysozyme (LZ), lactoferrin (LF), lactoperoxidase (LP), short peptidoglycan recognition protein (PGRP) all present in camel milk (Zeng et al., 2001; 2003).

Camel milk is gaining popularity because of scientific reports of its high nutritional qualities and therapeutic value (Abusheliabi et al., 2016). As such, camel milk composition has been widely studied throughout the world (Abbas et al., 2013; Abu-Lehia, 1989; Alimi et al., 2016; Asres \& Yusuf, 2014; Konuspayeva et al., 2009; Yadav et al., 2015). The findings of the present study confirm the therapeutic activity of fresh camel milk on $H$. polygyrus, a nematode parasite infecting mice.

There are unfortunately no similar results in the literature using camel milk with which our results can be compared. Nevertheless, studies in sheep (Zeng et al., 2001), cattle (Rohrbacher et al., 1958; Satrija et al., 1991), rabbits (Rohrbacher et al., 1958), horses (Leese, 1943), and pigs (Shorb \& Spindler 1947) have all demonstrated lower worm burdens in young mammals fed milk than in those weaned to solid feed or grass. Nevertheless, none of the previous studies tested camel milk.

Arguments to support the involvement of various components in milk have been adduced in some previous work; such benefits could accrue through a direct effect of milk on the nematode or indirectly through enhancement of the host immune response or of host resilience to the pathological effects of infection (Zeng et al., 2003).

Direct effects could operate through specific effects of milk components, for example, of oligosaccharides on the adhesion of pathogens to host mucosa (Hakkarainen et al., 2005), or of milk proteins and components associated with milk proteins on motility of nematode larvae (Zeng et al. 2003). However, indirect effects could operate via the superior amount and quality of proteins supplied by milk, which are protected from degradation in the rumen by the 
esophageal groove reflex, promoting greater or more rapid development of host immunity or greater host resilience to the pathogenic effects of infection; such effects were tested and confirmed in earlier works (Bown et al. 1991; Sykes \& Coop, 2001).

Another indirect effect which has been put forward regarding the resistance to parasitism of milk-fed animals is the high $\mathrm{pH}$ of milk which was suggested to protect against nematodes. Indeed, high $\mathrm{pH}$ of milk has been suggested as a possible contributing factor to low worm burdens in milk-fed calves (Rohrbacher et al., 1958) and is involved in increasing gut motility, hence causing expulsion of nematodes from skim-milk-fed pigs (Spindler et al., 1944).

With regards the more specific anthelmintic effect of camel milk, Agrawal et al. (2002; 2005) put forward the hypothesis that high content of lactoferrin in camel milk, acts as a prebiotic having a strong physiological activity in the gastrointestinal tract. It has also been suggested that lactoferrin possesses antiparasitic activity towards a broad spectrum of species, such as Pneumocystis carinii, Toxoplasma gondii and Tritrichomonas vaginalis. (Cirioni et al., 2000; Omata et al., 2001). The antiparasitic effect of lactoferrin is predominantly linked to iron sequestration and destabilization of the parasite membrane (Elbarbary et al., 2014).

The anthelminthic effects of camel milk may also be attributed to its antioxidant activity (Al-Humaid et al., 2010). Camel milk possesses high levels of vitamins $\left(B_{2}, C\right.$, and $\left.E\right)$ and is rich in mineral content (sodium, potassium, copper, magnesium, and zinc) (Al-Humaid et al., 2010; Nagy et al., 2013). Camel milk concentration in vitamin $C$ is 3 to 5 -fold higher than in bovine milk (Haddadin et al., 2008; Salwa \& Lina, 2010) and beyond its nutritional role; vitamin C exerts a powerful antioxidant activity (Abdel Galil et al., 2016). In addition, the high minerals content in camel milk (Nagy et al., 2013) may act as antioxidant, and thereby removes free radicals (Powell, 2000; Kumar et al., 2015).

\section{Conclusion}

This study has demonstrated the in vivo anti-parasitic effect of camel milk using the intestinal parasite $H$. polygyrus and its monogastric host the mouse with an observed reduction of faecal egg count by over $76 \%$. Our findings are backed by previous results from our laboratory on the in vitro anthelmintic effects of camel milk on $\mathrm{H}$. contortus. While the in vivo anthelmintic effects of camel milk needs to be proven using ruminant species, current results may have important implications for the control of gastrointestinal parasites. Additional work is suggested (i) to identify camel milk components responsible of reducing the parasite burden, (ii) to elucidate their mechanism of action and (iii) to test their efficacy against a broader spectrum of helminth classes like trematode, cestode and nematodes.

\section{Conflict of Interest}

All authors declare no conflict of interest.

\section{Acknowledgements}

We are grateful to Mr Sassi Limam, Mr Mohamed Jedidi, Mr Bechir Guesmi and Mr Tawfik Lahmar for their valuable technical assistance and to Dr. Rick Maizels (Wellcome Centre for Molecular Parasitology, University of Glasgow) for providing the parasite strain used in the study.

\section{References}

Abbas, S., Ashraf, H., NaziR, A., Sarfraz, L. (2013): Physico-chemical analysis and composition of camel milk. Int. Res. J., 2(2): 82 - 98 Abdel Galil, A.G.M., Alhaider, A.A. (2016): The unique medicinal properties of camel products: A review of the scientific evidence. J. Taibah Univ. Med. Sci., 11(2): 98 - 103. DOI: 10.1016/j. jtumed.2015.12.007

ABu-LehiA, I.H. (1989): Medical and Chemical Characteristics of Camel Milk fat and its fractions. Food Chem., 34(4): $261-271$. DOI: 10.1016/0308-8146(89)90103-9

Abusheliabi, A., Al-Rumaithi, H.O., Olaimat, A.N., Al-Nabulsi, A.T., OsAILI, T., SHAKER, R., AYYASH, M.M. (2017): Inhibitory effect of camel milk on Cronobacter sakazakii. J. Food Saf., 1 - 7. DOI: 10.1111/ jfs. 12343

Ademola, I.O., Fagbemi, B.O., Idowu, S.O. (2004): Evaluation of the anthelmintic activity of Khaya senegalensis extract against gastrointestinal nematodes of sheep: in vitro and in vivo studies. Vet Parasitol., 122(2):151 - 164. DOI: 10.1016/j.vetpar.2004.04.001

Adiele, R.C., FAKAe, B.B., Isuzu, I.U. (2013): Anthelmintic activity of Securidaca longepedunculata (Family: Polygalaceae) root extract in mice, in vitro and in vivo. Asian. Pac. J. Trop. Med., 6(11): 841 846. DOI: 10.1016/S1995-7645(13)60150-9

Agrawal, R.P., Swami, S.C., Beniwal, R., Kochar, D.K., Kotharl, R.P. (2003): Effect of camel milk on glycemic control, risk factors and diabetes quality of life in type 1 diabetes: A randomized prospective controlled study. J. Camel Pract. Res., 10(1): 45 - 50.

Agrawal, R.P., Sahani, M.S., Tuteja, F.C., Ghouri, S.K., Sena, D.S., GUPTA, R., KochAR, D.K. (2005): Hypoglycemic activity of camel milk in chemically pancreatectomized rats-an experimental study. Int. J. Diab. Dev. Countries., 25: 75 - 79. DOI: 10.4103/09733930.22776

Agrawal, R.P., Jain, S., Shah, S., Chopra, A. (2011): Effect of camel milk on glycemic control and insulin requirement in patients with type 1diabetes: 2- years randomized controlled trial. Eur. J. Clin. Nutr., 65: 1048 - 1052. DOI: 10.1038/ejcn.2011.98

Akkari, H., Jebali, J., Gharbi, M., Mhadhbi, M., Awadi, S., Darghouth, M.A. (2013): Epidemiological study of sympatric Haemonchus species and genetic characterization of Haemonchus contortus in domestic ruminants in Tunisia. Vet. Parasitol., 193(1 - 3): 118 125. DOI: 10.1016/j.vetpar.2012.12.014

Al HaJ, O.A., Al Kanhal, H.A. (2010): Compositional, technological and nutritional aspects of dromedary camel milk-Review. Int. Dairy J., 20(12): 811-821. DOI: 10.1016/j.idairyj.2010.04.003 
Al-Humaid, A.I., Mousa, H.M., El-Mergawi, R.A., Abdel-Salam, A.M. (2010): Chemical composition and antioxidant activity of dates and dates-camel-milk mixtures as a protective meal against lipid peroxidation in rats. Am. J. Food Technol., 5(1): 22 - 30. DOI: 10.3923/ajft.2010.22.30

Alimi, D., Hajajl, S., Rekik, M., Abidi, A., Gharbi, M., Akkari, H. (2016): First report of the in vitro nematicidal effects of camel Milk. Vet. Parasitol., 228: 153 - 159. DOI : 10.1016/j.vetpar.2016.09.003 Asres, A., Yusuf, M. (2014): Traditional consumption, therapeutic value and its derived dairy products of dromedary Camel (Camelus dromedaries) milk in Somali regional State, Eastern Ethiopia: A Review. Scholarly J. Agric. Sci., 4 (11): 548 - 552

Benkerroum, N., Mekkaoul, M., Bennani, N., Hidane, K. (2004): Antimicrobial activity of camel's milk against pathogenic strains of Escherichia coli and Listeria monocytogenes. Int. J. Dairy Technol., 57(1): 39 - 43. DOI: 10.1111/j.1471-0307.2004.00127.x

Bown, M.D., PopPI, D.P., SYkES, A.R. (1991): The effect of post-ruminal infusion of protein or energy on the pathophysiology of Trichostrongylus colubriformis infection and body composition in lambs. Aust. J. Agric. Res., 42: 253 - 267. DOI: 10.1071/ AR9910253

Britton, C., Winter, A.D., Marks, N.D., Gu, H., Mcneilly, T.N., GilLAN, V., DeVAneY, E. (2015): Application of small RNA technology for improved control of parasitic helminths. Vet. Parasitol., 212(1 - 2): 47 - 53. DOI: 10.1016/j.vetpar.2015.06.003

Cirioni, O., Giacometti, A., Barchiesi, F., Scalise, G. (2000): Inhibition of growth of Pneumocystis cariniiby lactoferrins alone and in combination with pyrimethamine, clarithromycin and minocycline. J. Antimicrob. Chemother., 46(4): 577 - 582. DOI: 10.1093/ jac/46.4.577

Coles, G.C., Bauer, C., Borgsteede, F.H.M., Greerts, S., Klei, T.R., TAYLOR, M.A., WalleR, P.J. (1992): World association for the advancement of veterinary parasitology (WAAVP) methods for the detection of anthelmintic resistance in nematodes of veterinary importance. Vet. Parasitol., 44(1 - 2): 35 - 44. DOI: 10.1016/03044017(92)90141-U

El-Agamy, E.I.M., Nawar, S.M., Shamsia, S., Awad, G.F., W. (2009): Are camel milk proteins convenient to the nutrition of cow milk allergic children. Small Rumin. Res., 82(1): 1 - 6. DOI: 10.1016/j. smallrumres.2008.12.016

Elbarbary, H.A., El-Nahas, E.M., Karam-Allah, E.L.E. (2014): Anti-rotaviral activity of whey proteins derived from milk of different animal species. Int. J. Adv. Res., 2(4): 214 - 221

ENRIQUEZ, J.B. (1993). Les médicaments anthelminthiques utilisés en médecine des carnivores domestiques. Activité et toxicité. [Anthelmintic drugs used in the medicine of domestic carnivores. Activity and toxicity.] Rec. Med. Vet., 189: $499-512$ (In French) Githiori, J.B., Hoglund, J., Waller, P.J., Baker, R.L. (2003a): The anthelmintic efficacy of the plant, Albizia anthelmintica, against the nematode parasites Heamonchus contortus of sheep and Heligmosomoides polygyrus of mice. Vet. Parasitol., 116(1): 23 - 34. DOI: 10.1016/S0304-4017(03)00218-8
Githiori, J.B., Hoglund, J., Waller, P.J., Baker, R.L. (2003b): Evaluation of anthelmintic properties of extracts from some plants used as livestock dewormers by pastoralist and small holder farmers in Kenya against Heligmosomoides polygyrus infections in mice. Vet. Parasitol., 118(3 - 4): 215 - 226. DOI: 10.1016/j. vetpar.2003.10.006

GITHIORI, J.B. (2004): Evaluation of anthelmintic properties of ethnoveterinary plants preparations used as livestock dewormers by pastoralist and small holder farmer in Kenya. PhD thesis. Kenya. Acta Universitatis Agricultural sulciae

Haddadin, M. S., GammoH., S.I., Robinson. R.K. (2008): Seasonal variation in the chemical composition of camel milk in Jordan. J. Dairy Res., 75 (1): 8 - 12. DOI: 10.1017/S0022029907002750

Hakkarainen, J., Tolvanen, M., Leinonen, A., Frängsmyr, L., Stromberg, N., Lapinjoki, S., Nassif, X., Tikkanen-Kaukanen, C. (2005): Human and bovine milk oligosaccharides inhibit Neisseria meningitidis pili attachment in vitro. J. Nutr., 135(10): 2445 - 2448

Konuspayeva, G., Faye, B., Loiseau, G. (2009): The composition of camel milk: a metaanalysis of the literature data. J. Food Compos. Anal., 22(2): 95 - 101. DOI: 10.1016/j.jfca.2008.09.008

KuLA, J. (2015): Medicinal Values of Camel Milk. Int. J. Vet. Sci. Res., 2 (1): 018 - 025

Kumar, Y.K., Rakesh, K., Lakshmi, P., Jitendra, S. (2015): Composition and medicinal properties of camel milk:AReview. Asian J. Dairy Food Res., 34(2): 83 - 91. DOI: 10.5958/0976-0563.2015.00018.4 LAHLOU, M. (2013): The success of natural products in drug discovery. Pharmacol. Pharm., 4: 17 -31. DOI: 10.4236/pp.2013.43A003 LeESE, A.S. (1943): Parasitic aneurism in foal. Vet. J., 99: 276 Miller, C.M., Waghorn, T.S., Leathwick, D.M., Candy, P.M., OliVER, A.M.B., Watson, TG. (2012): The production cost of anthelmintic resistance in lambs. Vet. Parasitol., 186: 376 - 381. DOI: 10.1016/j.vetpar.2011.11.063

Nagy, P., Thomas, S., Markó, O., JuHÁsz, J. (2013): Milk production, raw milk quality and fertility of dromedary camels (Camelus Dromedarius) under intensive management. Acta Vet. Hung., 61(1): 71 - 84. DOI: 10.1556/AVet.2012.051

Martinez-Valladares, M., Geurden, T., Bartram, D.J., Martinez-Perez, J.M., Robles-Perez, D., Bohorquez, A., Florez, E., MeANA, A., Rojo-Vazquez, F.A. (2015): Resistance of gastrointestinal nematodes to the most commonly used anthelmintics in sheep, cattle and horses in Spain. Vet. Parasitol., 211(3 - 4): 228-233. DOI: 10.1016/j.vetpar.2015.05.024

Omata, Y., Satake, M., Maeda, R., Saito, A., Shimazaki, K., Yamauchi, K., Uzuka, Y., Tanabe, S., Sarashina, T., Mikami, T. (2001): Reduction of the infectivity of Toxoplasma gondii and Eimeria stiedai sporozoites by treatment with bovine lactoferrin. J. Vet. Med. Sci., 63(2): 187 - 190. DOI: 10.1292/jvms.63.187

Porter, D.A. (1941): The effect of milk diet on the development of Haemonchus contortus in calves. J. Parasitol., 27: 18 - 19

PowelL, S.R. (2000): The antioxidant properties of zinc. J. Nutr., 130(5): $1447-1454$

Rohrbacher, G.H., Porter, D.A., Herlich, H. (1958): The effect 
of milk in the diet of calves and rabbits upon the development of trichostrongylid nematodes. Am. J. Vet. Res., 19: 625 - 631

Rouatbi, M., Gharbi, M., RJeibi, M.R., Ben Salem, I., AkkarI, H., LasSOUED, N., REKIK, M. (2016): Effect of the infection with the nematode Haemonchus contortus (Strongylida: Trichostrongylidae) on the haematological, biochemical, clinical and reproductive traits in rams. J. Vet. Res., 83(1): 1 - 8. DOI: 10.4102/ojvr.v83i1.1129

SALWA, M.K., LINA, A.F.K. (2010): Antigenotoxic and anticytotoxic effect of camel milk in mice treated with cisplatin. Saudi. J. Biol. Sci., 17(2): 159 - 166. DOI: 10.1016/j.sjbs.2010.02.010

SatriJa, F., Nansen, P., Christensen, C.M. (1991): Ostertagia ostertagi in neonatal calves, establishement in infection of ruminating and non ruminating calves. Res. Vet. Sci., 51(3): 125 - 139. DOI: 10.1016/0034-5288(91)90091-2

SHORB, D.A., SpInDLER, L.A. (1947): Growth rate of pigs fed skim milk to control intestinal parasites. Proc. Helminthol. Soc. Wash., 14 (1): $30-34$

SмYтH, J. D. (1996): Animal parasitology. Cambridge University Press, London, pp.1 - 549

Spindler, L.A., Zimmerman, H.E. (1944): Effect of skim milk on the growth and acquisition of parasites by pigs under conditions of constant exposure to infection. Proc. Helminthol. Soc. Wash., 11: $49-54$

Spindler, L.A., Zimmerman, H.E., Hill, C.H. (1944): Preliminary observations of the control of worm parasites in swine by the use of skim milk. Proc. Helminthol. Soc. Wash., 11: 9 - 12

SYKES, A.R., COOP, R.L. (2001): Interactions between nutrition and gastrointestinal parasitism in sheep. N. Z. Vet. J., 49(6): $222-226$. DOI: 10.1080/00480169.2001.36236

Thienpont, D., Rochette, F., Vanparius, O. (1979): Diagnostic des verminoses par examen coproscopique [Diagnosing helminthiasis by coprological examination]. Beerse, Belgique, Janssen Research Foundation 187 pp. (In French)

Yadav, A.K., Kumar, R., Priyadarshin, L., Singh, J. (2015): Composition and medicinal properties of camel milk: A Review. Asian J. Dairy Food Res., 34(2): 83 - 91. DOI: 10.5958/09760563.2015.00018.4

Yassin, M.H., Soliman, M.M., Mostafa, S.A.E., Ali, H.A.M. (2015): Antimicrobial Effects of Camel Milk against Some Bacterial Pathogens. J. Food Nutr. Res., 3(3): 162 - 168. DOI: 10.12691/jfnr-3-3-6 Yondo, J., Komtangi, M.C., Wabo, J. P., Bilong Bilong, C.F., Kuiate, J.R., MPOAmE, M. (2013): Nematicidal efficacy of methanol/methylene chloride extract of Rauwolfia vomitoria (Apocynacae) on Heligmosomoides bakeri (Nematoda, Heligmosomatidae) parasite of the white mouse (Mus musculus). J. Med. Plant Res., 7(34): 3220 - 3225. DOI: 10.5897/JMPR2013.5160

Zeng, S., Lawton, D.E.B., Przemeck, S.M.C., Simcock, D.C., Simpson, H.V. (2001): Reduced Ostertagia circumcincta burdens in milk-fed lambs. N. Z. Vet. J., 49(1):2-7.DOI:10.1080/00480169.2001.36194 Zeng, S., Brown, S., Przemeck, S.M.C., Simpson, H.V. (2003): Milk and milk components reduce the motility of Ostertagia circumcincta larvae in vitro. N. Z. Vet. J., 51(4): 174 - 178. DOI: 10.1080/00480169.2003.36360 